\title{
Doğal Afetlerin Çocuklar ve Ergenler Üzerindeki Etkileri
}

\author{
Derya Karabulut ${ }^{1} \oplus$, Tolga Bekler ${ }^{2,3, *}$
}

${ }^{1}$ Rize II Sağlık Müdürlüğü, Merkez 2 No'lu Acil Sağlık Hizmetleri İstasyonu, Rize.

${ }^{2}$ Çanakkale Onsekiz Mart Üniversitesi, Mühendislik Fakültesi, Jeofizik Mühendisliği, Çanakkale.

${ }^{3}$ Çanakkale Onsekiz Mart Üniversitesi, Deprem Araştırma Uygulama ve Araştırma Merkezi, Çanakkale.

\section{Özet}

Doğal afetler öngörülemeyen, etkileyeceği alan ve etki düzeyi tahmin edilemeyen, çok fazla sayıda can ve mal kayıpları ile sonuçlanabilen doğa olaylarıdır. Dünya genelinde ve ülkemizde her yıl birbirinden farklı doğal afetlerin yaşandığına ve bu afetlerin sonuçlarının toplumlar üzerindeki etkilerine şahit oluyoruz. Çocuklar ve ergenler afetlere maruz kalan ve afetlerden etkilenen grupların en hassas ve savunması bireyleridir. Her yıl dünya üzerinde milyonlarca çocuk ve genç doğal ve insan kaynaklı afetlere maruz kalmakta ve bu afetlerden farkl şekillerde etkilenmektedir. Bu çalışma, doğal afetlerin çocuklar ve gençler üzerindeki etkilerine yönelik farkındalık oluşturmak amacılla yapılmıştır. Başta Yöktez, Google Scholar, Dergi Park, EM-DAT, Science Direct, PubMed, Psikiyatri ve Psikoloji Araştırmaları Dergisi, Uluslararası Aile Çocuk ve Ĕgitim Dergisi olmak üzere konu ile ilgili bilgi erişimini sağlayan veri tabanları kullanılarak, afet, doğal afet, afet etkileri, afetler ve çocuklar, afetler ve gençler, çocuk gelişimi araştırmamıza temel teşkil eden gruplar kullanılarak elde edilen tezler ve makaleler irdelenmiştir. Konu ile ilgili çalışmalar; ilerde yapılacak yeni araștırmalara veri tabanı olabilecek șekilde genel olarak değerlendirilerek ve yorumlanarak bir araya getirilmiștir.

Anahtar Sözcükler

Doğal Afetler, Çevre, İnsan

\section{Effects of Natural Disasters on Children and Adolescents}

\begin{abstract}
Natural disasters are unpredictable natural phenomena that can result in a large number of life and property losses, with an unknown level of impact. We are witnessing different natural disasters every year in the world and in our country, and the effects of these disasters on communities. Children and adolescent people are the most sensitive and vulnerable individuals when exposed to disasters. Every year, millions of children and young people around the world are exposed and affected by various natural and man-made disasters. This study was conducted to raise awareness of the effects of natural disasters on children and adolescents. Theses and articles obtained by using search words and phrases such as disaster, natural disasters, disaster effects, disasters and children, disasters and young people, child development from different databases such as Yöktez, Google Scholar, Dergi Park, EM-DAT, Science Direct, PubMed, International Journal of Psychiatry and Psychology Studies, International Journal of Family Child and Education, have been reviewed and interpolated as to form a data base for further studies.
\end{abstract}

Keywords

Natural Hazards, Environment, People

\section{Giriş}

Doğanın olağan düzeninin insanoğlu tarafından bozulması sonucunda doğa olayları felaketlere dönüşür. Karşı konulamaz büyüklükteki felaketler yüzyıllardır can ve mal kayıplarına neden olmaktadır. Her yıl dünyanın farklı yerlerinde milyonlarca çocuk ve ergen birey doğal ve insan kaynaklı afetlere maruz kalmakta ve bu afetlerden çeşitli şekillerde etkilenmektedir. Ülkemizde afetlerin çocuklar ve ergenlik dönemi üzerindeki etkilerini araştıran ilk çalışmalar 1992 Erzincan ve 1995 Dinar depremleri ile başlamıştır. 17 Ağustos ve 12 Kasım 1999 Marmara depremleri ile de çalışmalar hız kazanmıştır (Bulut 2009). Dünyada ve ülkemizde doğal afetlerin çocuklar ve başta ergenler olmak üzere gençler üzerindeki etkilerini konu alan çalışmaların çoğunluğu afetlerin psikolojik etkilerinden olan Travma Sonrası Stres Bozukluğu (TSSB) belirtilerine odaklanmıştır. Ancak, afetlerin çocuklar ve ergenler üzerindeki etkileri sadece davranış bozuklukları ile sınırlı değildir. Uzmanlar için doğal afet deneyimleri çocukluk döneminde yaşaması beklenilen deneyimlerin dışındadır. Çocukların tam olarak gelişmemiş bilişsel ve sözel ifade yetenekleri ve duygularını yetişkinler gibi ifade edememeleri doğal afetlerden etkilenmedikleri anlamına gelmez. Aksine, çocuklar ve ergenler afetlerin etkilediği en hassas ve savunmasız afet mağdurlarıdır. 


\section{Veri ve Tanımlamalar}

Dünyamızı etkileyen doğa olayları, doğanın olağan bir döngüsüdür. İnsan kaynaklı yapılanların doğa dengesini bozması sonucunda, zaman içerisinde meydana gelen olaylarının şiddeti, sıklığı, etkisi artmaya başlamış ve insanoğlu tarafından bu olaylar "afet" olarak adlandırılır olmuştur. Afet ve Acil Durum Yönetimi Başkanlığı (AFAD) tarafından hazırlanan Açıklamalı Afet Yönetimi Terimleri sözlüğünde afet terimi toplumun tamamı veya belirli bir kesimi için yaralanmalara veya can kayıplarına neden olan, ekonomik ve sosyal kayıplar doğuran, normal hayatı ve insani faaliyetlerini kesintiye uğratarak aksatan veya tamamen durduran, etkilenen toplumun mevcut imkânları ile baş etme kapasitesinin yeterli olmadığı doğa, teknoloji veya insan kaynaklı olaylar şeklinde tanımlanmıştır (AFAD 2014).

Birleşmiş Milletler (BM) tarafından yapılan afet tanımına göre ise 'afet'; etkilenen bireyler için fiziksel yaralanmalara, can ve mal kayıplara neden olan, sosyal hayatı ve normal yaşamı durdurarak ya da kesintiye uğratarak toplumları etkileyen ve etkilenen toplumlar tarafindan yerel imkânlar ile baş edilemeyen doğal, teknolojik veya insan kaynaklı yaşanan her türlü olaylar olarak ifade edilir (Kadıoğlu 2011).

Dünya genelinde yaklaşık 52 afet çeşidinin varlığından söz edilmektedir. Bunların içinden tahmini olarak 21 afet türünün Türkiye'de gerçekleştiği düşünülmektedir (Işık vd. 2012). Literatürde afetler için kabul edilmiş ortak bir sınıflandırma türü bulunmamaktadır. Araştırmacılar afetleri farklı tür ve tanımlarda sınıflandırmışlardır. Bazı araştırmacılar şekil 1'de görüldüğü gibi afetleri en genel hali ile doğal afetler ve insan kaynaklı afetler olarak ikiye ayırmışlardır (Gökçe ve Tetik 2012).

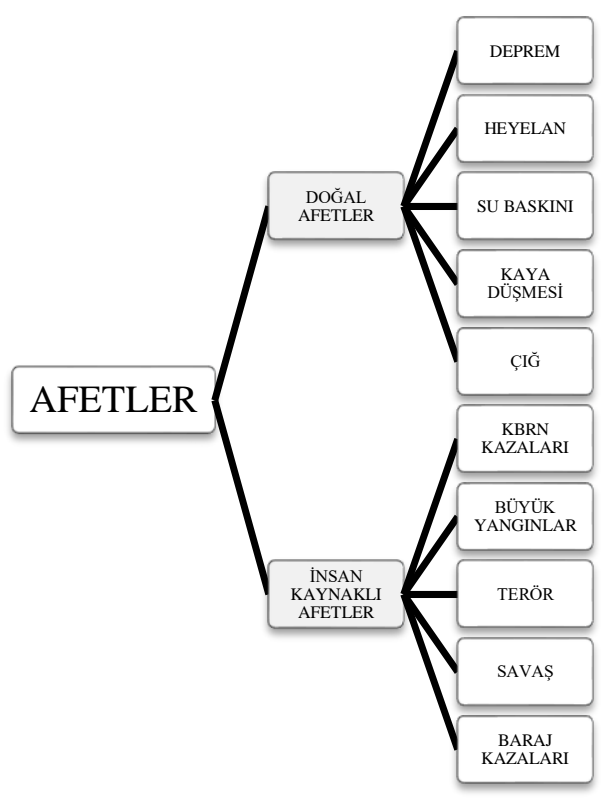

Şekil 1: Doğal ve insan kaynaklı afetler (Gökçe ve Tetik 2012)

Doğal afetler etkilediği toplumların sosyoekonomik ve sosyokültürel faaliyetlerini önemli ölçüde durduran ya da aksatan, fiziksel yaralanmalara, sakatlanmalara, can ve mal kayıplarına neden olan, depremler, ani sel ve su baskınları, rüzgar, toz, kum, yağmur, kar ve kış firtınaları, don olayları, çığlar, firtınalar, hortumlar, zemin çökmesi, heyelanlar, çamur akıntısı, kaya düşmesi, orman ve çalı yangınları, buzlanma, deniz ve göl su seviye değişimleri, tsunami, çölleşme, kuraklık, sıcak ve soğuk hava dalgaları, sis ve düşük görüş mesafesi, tarımsal zararlılar, çekirge istilaları, yıldırımlar, salgın hastalıklar gibi olaylardır (Kadıoğlu 2008). Diğer yandan doğal afetler için jeolojik kökenli doğal afetler ve meteorolojik kökenli doğal afetler sınıflandırması kullanımı da yaygındır. Dünya genelindeki otuz bir çeşit doğal afetin yirmi sekizini meteorolojik afetlerin oluşturduğu düşünülmektedir (Işı1k vd. 2012). 


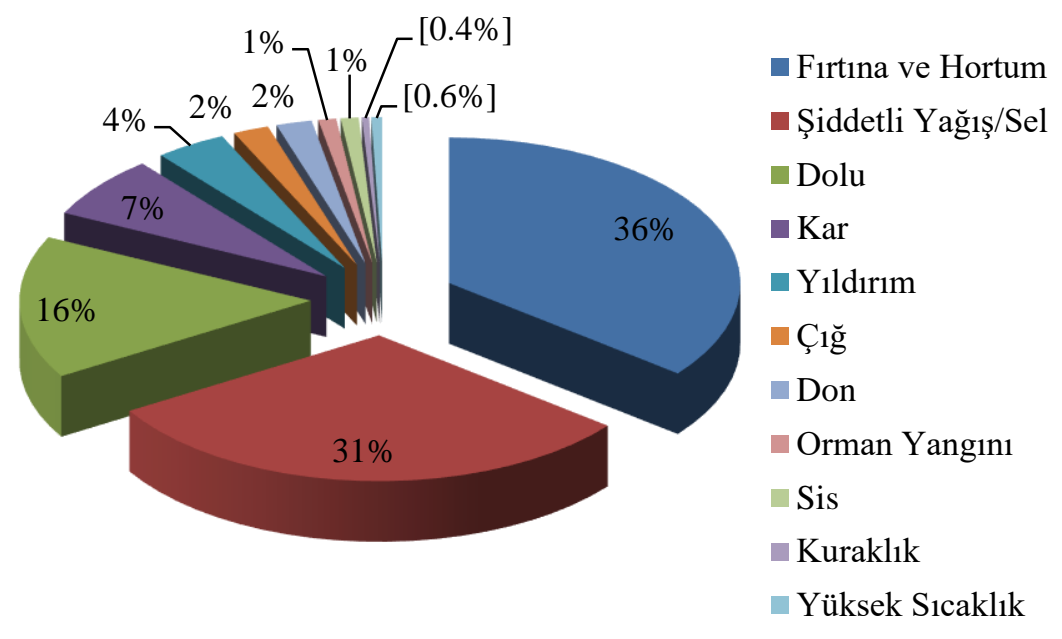

Şekil 2: 2017 yılı olağanüstü olayların oransal dağılımları (MGM 2018)

Şekil 2'de görüldüğü gibi 2017 yılında Türkiye'de meydana gelen meteorolojik kökenli olayların; \%36'sını fırtına ve hortumlar, \%31'ini şiddetli yağışlar ve sel, \%16'sını dolu, \%7'sini kuvvetli kar yağışları, yaklaşık \%4'ünü yıldırım olayları, yaklaşık \%1,5'ini çığ ve don olayları ve \%1'lik kısmını ise diğer küçük meteorolojik olaylar oluşturmuştur (MGM 2018). Doğal afetler içinde yaşanma süreci ve etki alanı en fazla olan depremlerdir. Depremler tektonik kuvvetlerin veya volkanik faaliyetlerin etkisi sonucunda yer kabuğunda meydana gelen kırılmalar ile ortaya çıkan enerjinin sismik dalgalar halinde yayılarak geçtikleri ortamları ve yeryüzünü kuvvetle sarsması olayıdır (AFAD 2014). Afet ve Acil Durum Yönetimi Başkanlığ1-Deprem Dairesi Başkanlığg Genel İstatistikler veri tabanından elde edilen bilgilere göre 1990-2018 yılları arasında ülkemizde 2'den büyük 280.000 deprem meydana gelmiştir (Şekil 3).

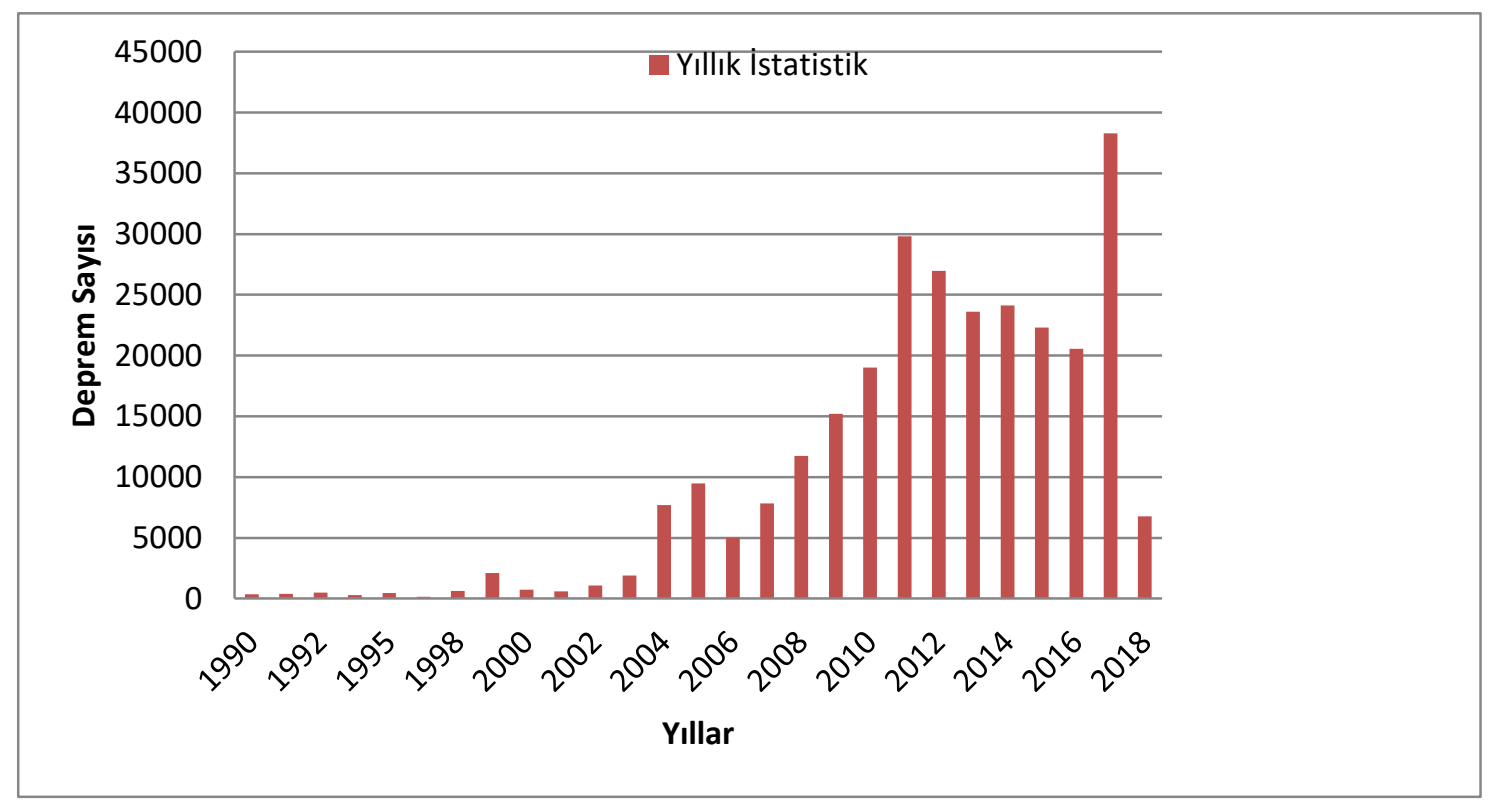

Şekil 3: Türkiye'de 1990-2018 yıllarında meydana gelen deprem sayıları

\section{Afetlerin Etkileri}

Yaşanan afetlerin temelde neden oldukları en önemli zarar can kayıpları olsa da ülkelerin ekonomilerine de ciddi birer darbedir (Sawada ve Takasaki 2017). Ekonomik Kalkınma ve İşbirliği Örgütü (OECD) afetlerin insanlar ve çevre üzerindeki etkilerini dört ana başlıkta ele alarak tanımlamıştır (Yavuz ve Dikmen 2015). Bu etkiler;

a. Yaralananlardan, sakat kalanlardan, zarar görenlerden ve hayatını kaybedenlerden oluşan fiziksel etkiler,

b. Bireylerin sosyal ve toplumsal yaşamlarını etkileyen yapı, altyapı ve tarım sistemleri gibi fiziksel hasarlardan oluşan fiziksel etkiler,

c. Yaşanan zararın mali ve ekonomik sonuçlarından oluşan ekonomik etkiler, 
d. Sağ kurtulanların afet sonrası yaşadığı fiziksel, ruhsal ve sosyal travmaların oluşturduğu sosyolojik etkiler olarak siralanabilir.

Doğa ve insan kaynaklı afetlerden etkilenen bireyler psikososyal, sosyo-demografik, sosyoekonomik ve sosyo-politik değişiklikler oluşturur. Psikososyal belirtiler duygu, davranış, psikofizyolojik ya da bilinç değişiklikleri ile kendini gösterir. Etkilenen çocuk ve ergen bireylerde yaş gruplarına göre değişiklik göstermek ile birlikte anksiyete ve kayg1 bozukluklarından başlayarak depresyona kadar ilerleyebilen duygu durum değişiklikleri, davranış bozuklukları, psikofizyolojik tepkiler ve bilişsel değişiklikler gözlemlenebilmektedir (Yavuz ve Dikmen 2015).

Afetlerin, sosyoekonomik değişiklikler sonucu oluşan sosyal etkileri ise doğrudan ve dolaylı afet maliyetlerini tanımlamaktadır. Doğrudan afet maliyeti; etkilenen alanlarda oluşan yapı hasarları, stok, tarım alanlarının ve ürünlerinin kaybı, altyapı hasarları, afet anında ve sonrasında yapılan acil müdahale, enkazdan kurtarma, iyileştirme ve rehabilitasyon süreci ile yeniden inşa çalışmalarına yönelik harcamaları kapsar. Dolaylı afet maliyeti ise ulaşım, ticaret, turizm, sağlık, eğitim, enerji gibi hizmet alanlarındaki aksamalar nedeniyle yaşanan hizmet ve ürünlerin kaybını kapsamaktadır (AFAD 2014).

\subsection{Afetlerden Etkilenen Gruplar}

Yaşanan her afetin ardında dört farklı afet mağduru grup tanımlanır. Bu gruplar aşağıda sıralanmıştır (Akyılmaz ve Karka 2011).

1. Derece etkilenenler: Afet bölgesinde yaşayan ve afetin etkilerine doğrudan maruz kalmış bireyleri tanımlar.

2. Derece etkilenenler: Doğrudan afet etkilerine maruz kalmış birincil mağdurlar ile ailevi veya kişisel bir bağı bulunan bireylerin oluşturduğu gruptur.

3. Derece etkilenenler: Afetzedelere hizmet götürmek ve yardım etmek için afet bölgesine giden bireyleri kapsar.

4. Derece etkilenenler: Afetlerin etkilerini ve afetzedeleri kitle iletişim araçları ile medya üzerinden takip eden bireylerden oluşur.

\subsection{Fiziksel Etkiler}

Sağlığın dünya genelinde kabul görmüş tanımında bireyin hastalık ya da sakatlığının bulunmaması yeterli görülmemiştir. Ayrıca, fiziksel, ruhsal ve sosyal yönden de tam bir iyilik halinin gerekliliği de vurgulanmıştır (Bulakbaşı 2015). Çocukluk çağında yaşanan doğal afetlerin yarattığı travma etkilerine bağlı olarak ifade edilen somatik yakınmalar yaygın bir tepki olarak karşımıza çıkmaktadır (Hensley ve Varela 2008). Afet mağdurları sağlıklı bir grup ile karşılaştırıldığında; psikolojik bozuklukların, kas iskelet sistemi sorunlarının, alt ve üst uzuv (ekstremite) rahatsızlıklarının ve solunum problemlerinin gelişimi açısından riskli bulunmuşlardır. Küçük yaş grubundaki afetzede çocukların kendi yaş grubundaki çocuklar ile karşılaştırılmasında ise sindirim sistemi (Gastrointestinal Sistem) sorunlarının ve uyku bozukluklarının daha fazla bildirildiği sonucuna varılmıştır (Felix vd. 2016).

Doğal afetlerin çocukların, ergen ve gençlerin sağlı̆̆ı üzerine olan etkilerin anlamak afet planlamalarında halk sağlı̆̆ politikası oluşturmanın ilk adımıdır (Maclean vd. 2016). Yaşanan sağlık sorunlarının değerlendirilmesinde bu dönemlere ait gelişim süreçlerinin hassasiyetleri göz ardı edilmemelidir. Her doğal afetin kendine özgü sağlık riskleri barındırdığ da unutulmamalıdır (Özcebe 2013).Vücudu bir kalkan gibi saran deri, kas ve kemik dokusunun, damar ve sinir yapılarının bütünlüğünün zarar görmesi, geçici bir süreliğine ya da tamamen dokunun fizyolojik ve derinin koruyuculuk özelliklerinin yitirilmesi ve vücudun enfeksiyon etkenlerine karşı savunmasız hale gelmesi yaralanma (travma) olarak tanımlanır (MEB 2011).Tüm dünyada yaralanmalar çocuk ölümlerinin ve sakatlanmalarının temel faktörü (Arpac1 vd. 2011), doğal afetlerde ise en sık karşılaşılan sağlık problemlerinin ilk sırada yer alan nedenidir (Özcebe 2013). Afetlerin türüne göre yaralanma şekilleri değişiklik gösterse de çoğunlukla yumuşak doku yaralanmaları, laserasyon yaraları, kesici ve delici alet yaralanmaları, kas iskelet sistemine ait yaralanmalar, göğüs (toraks) ve omurilik yaralanmaları, kırıklar, burkulmalar ve kapalı kafa travmaları görülür (Özcebe 2013; Yıldız 2013).

Doğal afetlerden sonra bozulan alt yapı, değişen çevre şartları, temiz su ve besin kaynaklarının temininde yaşanan güçlükler, katı ve sıvı atık kontrollerinin yeterince sağlanamaması, sağlık hizmetlerinin aksaması veya durması, çocuklarda aşı eksikliğine bağlı gelişebilen bağışıklık sistemi sorunları, kalabalık yaşam alanlarında dört haftadan daha uzun süre yaşamak zorunda kalınması, kişisel temizliğin yeterince yapılamaması, bulaşıcı hastalıklara ve korunma yollarına dair bilgi eksiklikleri, başıboş hayvan ve vektör kontrollerinin yeterince sağlanamaması, hayatını kaybetmiş bireylerin defin işlemlerinin geciktirilmesi, cesetlerin kamp alanlarına yakın yerlerde ve sağlıksız koşullarda muhafaza edilmesi gibi birçok etken afetlerden sonra çocuklarda hem bulaşıcı hastalık görülme riskini hem de bu hastalıkların yayılma hızını artırır (Watson vd. 2007; Özcebe 2013; Ekşi 2016; Pascapurnama vd. 2018). Doğal afetlerden sonra meydana gelen çocuk ölümlerinin dörtte üçünden fazlası bulaşıcı hastalıklara bağlı gelişir (Gözübüyük vd. 2015).

Doğal afetlerden sonra özellikle bebeklerin düzenli ve sık aralıklarla emzirilmesi; şiddetli beslenme bozukluğuna bağlı hipoglisemi (kan glikoz düzeyinin düşmesi) ve fizyolojik sarılık gelişiminin önlenmesinde etkili bir yoldur. Bu yüzden doğal afetlerden sonra emziren annelerin sıvı ve besin alımı desteklenmelidir. Yaşanan beslenme sorunları çocukların geleceğe karamsar ve umutsuz bakan bireyler haline gelmelerine neden olabilir (Lynch vd. 2010). 
İdeal kilosunun \%70'ini kaybetmiş, yeterli protein ve enerji içerikli besin alımı sağlayamayan, ishal, kızamık ve tüberküloz gibi sağlık sorunları yaşayan çocuklara özel tıbbi bakım ve tedavi edici beslenme programı desteği uygulanmalıdır (Aycan vd. 2002). Riskli gruplardaki çocukların olası beslenme sorunları düzenli olarak takip edilmeli ve nedenleri araştırılmalıdır. Çocukların doğal afetlerden önceki beslenme düzenlerine en kısa sürede tekrar kavuşturulması; onların afetlerin olumsuz etkileri ile baş edebilme kapasitelerini artırır (Oral vd. 2017).

\subsection{Sosyal Etkiler}

Doğal afetlerden sonra bozulan sosyal düzen, ekonomik ve güvenlik kaygıları göçlere neden olur. Bu yer değişiklikleri bazen isteğe bağlı bazen de zorunlu göçler şeklinde gerçekleşir (Ekici ve Tuncel 2015). Afet mağduru bireylerin yaşam alanlarına karşı güvenlerinin azalması ve tekrar bir afete maruz kalma korkusu ile yaptıkları yer değişikliklerine geçici göç denilmektedir. Afet mağduru bireylerin afet tehlikesi sona erdikten sonra tekrar yaşadıkları yere geri dönmediği durum ise kalıcı göç olarak adlandırılır. Göç olgusu doğal afetlerin çocuklar ve ergenler üzerindeki en önemli sosyal etkisidir (Leblebici 2004).

Yaşadıkları yerleri terk etmek zorunda kalan çocuklar ve ergenler yeni yaşam alanlarında dil, din, kültür gibi nedenlere bağlı uyum sorunları yaşayabilmektedir. Zayıf sosyoekonomik nedenlerle küçük yaşlarda çalışmak zorunda kalan çocuk ve ergenlerin eğitim hayatlarında aksamalar yaşanabilmekte ve akademik başarılarında düşüşler görülebilmektedir. Tüm bu güçlükler beraberinde psikolojik sorunların da yaşanmasına neden olabilmektedir (Kaştan 2015).

Doğal afetlerden sonra yaşanan göçün çocuklar üzerindeki etkilerini araştırmak üzere bir çalışma yapılmıştır (Hansel vd. 2013). Bu çalışmaya göre; 2005'te meydana gelen Katrina Kasırgası'ndan sonra yaşadığı yerden başka bir şehre göç etmek zorunda kalan öğrencilerin TSSB ve depresyon belirtilerini daha fazla gösterdiği sonucuna ulaşılmıştır. Ayrıca bu belirtiler afet bölgesine geri dönen öğrencilere göre geri dönmeyen öğrencilerde daha fazla kronikleşme göstermektedir.

\subsection{Davranışsal Etkileri}

Çocuklar ve ergenlik dönemi içindeki bireyler tarafından doğal afetlere karşı gösterilen davranışsal değişiklikler yetişkinlerin afet davranışlarından farklılık gösterse de çocukların davranışlarında yetişkinlerin afet tepkilerinin izleri gözlemlenir (Pfefferbaum vd. 2008). Ancak her çocuk doğal afetlerden sonra aynı davranışsal tepkiyi göstermeyebilir (Felix vd. 2011). Çocuklarda gözlemlenen davranış değişiklikleri içinde bulundukları gelişim döneminin özelliklerini de yansıtmaktadır (Akcanbaş 2009). Çocuklarda afetlerden sonra görülen davranış değişikliklerini etkileyen faktörler (Pfefferbaum vd. 2008); doğal bir afete ait faktörler ve bu afete maruz kalma ile ilgili bileşenler olarak ifade edilebilir. Çocukların gelişim dönemlerine göre doğal afetlerden sonra gözlemlenen davranış değişiklikleri aşağıda açıklanmıştır.

Oyun Çă̆ı (3-5 Yaş) Dönemi: Çocuklar doğal afeti bizzat yaşamış ya da medya vasıtası ile sadece yaşananlara tanık olmuş olabilir. Hangi şekilde afete maruz kalmış olursa olsun, doğal afetler çocuklarda tepkisel davranış değişiklikleri meydana getirir. Değişen yaşam koşulları ve bozulan sosyal düzen çocukların uyum sorunları yaşamasına neden olur. Özellikle bu yaş grubunda maruz kalınan doğal afetin etkisi ile korku, şaşkınlık ve güvensizlik hali sık görülür (Erden vd. 2009; Erden vd. 2011). Ayrıca, doğal afetlerin neden olduğu kayıpları hatırlatan oyunlar oynama, yaşananları öykü gibi sürekli anlatma, doğal afetlerle ilgili ısrarcı bir şekilde sorular sorma ile de kendini gösterebilir (Erden vd. 2011). Kekemelik gibi konuşma bozuklukları ve aşırı strese bağlı sağlık sorunları da gelişebilir (Limoncu ve Atmaca 2018; Erden vd. 2011).

Okul Çă̆l (6-11 Yaş) Dönemi: Bu yaş grubundaki çocuklar, artık olayların farkına varabilecek olgunluğa erişmişlerdir. Hayatlarında meydana gelebilecek değişikliklere ve yaşamlarını etkileyebilecek tehlikelere karşı gerçekçi bir bakış açıları vardır. Çocuklar yetişkinlerin de afetlere karşı savunmasız ve zayıf olduklarını görerek onlara karşı güven kaybı yaşayabilirler. Ayrıca itaatsizlik ya da ebeveynlere aşırı bağlanma davranışları da gözlemlenebilir (İşmen 2001). Bu yaş grubu için okul arkadaşları ve akran ilişkileri çok önemlidir. Arkadaşlarını kaybetme ya da arkadaşlarından ayrılma gibi bir durum yaşadıklarında depresyona kadar giden psikolojik sorunlar yaşanabilir (Coffman 1998).

Ergenlik Dönemi: Dünya Sağlık Örgütü (WHO) ergenlik dönemini 10- 19 yaş aralığ olarak ele alır (Özcebe 2013). UNESCO ergenliği 15 ile 25 yaş aralığını kapsayan, bireyin eğitim ve öğretim hayatına ve bekar yaşamına devam ettiği, henüz ekonomik bağımsızlığını elde etmediği dönem olarak tanımlar. Birleşmiş Milletler ise ergenlik dönemini kapsayan yaş aralığını 12-25 olarak değerlendirmektedir. Bazı kaynaklarda ergenlik dönemi için benzer yaş sınıflandırmaları yapılsa da net bir yaş aralığı söylemek doğru değildir. Çünkü bireyin beslenme şekli, yaşadığı yerin iklimi, cinsiyet ve irk özellikleri gibi birçok faktör ergenlik sürecinin gelişimini etkilemektedir (Koç 2004).

Yaşanan bedensel, ruhsal ve sosyal değişimlere uyum sağlamaya çalışırken, bir de doğal afette maruz kalmış olmak ergenlerin afetlerden daha fazla olumsuz etkilenmelerine neden olur (Erden vd. 2011). Doğal afetlerden sonra mevcut yaşam koşullarının ve çevre düzeninin bozulmasına bağlı olarak afetin ilk haftalarında uyku bozuklukları görülebilir (Limoncu ve Atmaca 2018).

Ergenlerde yaşanan olaylardan uzaklaşmak için madde kullanımına yönelmeler görülebilir. Madde kullanımına bağlı saldırganlık ve suç işleme oranları da artabilmektedir. Araştırmalardan elde edilen sonuçlara göre, ergenlerde en çok kullanılan maddenin \%94,4’lük bir oranla sigara olduğu görülmektedir (Yüksel 2016). 


\subsection{Psikolojik Etkiler}

Doğal afetlerin çocuklar ve ergen bireyler üzerindeki psikolojik etkilerini inceleyen çalışmaların çoğu TSSB ve depresyon belirtileri üzerinde yoğunlaşmıştır (Cheng vd. 2018; Felix vd. 2011). Ancak doğal afetlerden sonra her çocuğun aynı psikolojik sorunu yaşayacağını düşünmek yanlış bir inanış olacaktır. Yapılan çalışmalarda TSSB, depresyon, genel anksiyete ve patolojik yas tepkilerinin doğal afetlerden sonra çocuklarda en sik görülen psikolojik etkiler olduğu sonucuna varılmıștır (Hansel vd. 2015; Felix vd. 2011; Karakaya vd. 2004).

Travma Sonrası Stres Bozukluğu (TSSB): Çocukların kendisine ya da bir başkasına yönelik bir ölüm tehdidi yaşaması, fiziksel bütünlüğüne yönelik bir saldırı veya yaralamaya maruz kalması ya da tanık olması sonucunda ortaya çıkan davranış değişikliklerini ifade eder (Göktepe 2014).

Depresyon: Duygusal karmaşanın hakim olduğu, çocukta sürekli bir gerginlik, hoşnutsuzluk, mutsuzluk, hiçbir şeyden zevk alamama, olumsuz ve kötümser düşüncelerin hakim olması, intihar teşebbüsünde bulunma ya da intihar düşüncesi, madde kullanım bozukluklarının gelişmesi, yeme ve uyku bozuklukları ile seyreden psikolojik bir bozukluktur. Anhedoni yani çocukların daha önce yapmaktan zevk aldıkları etkinliklerden artık zevk alamaması ya da bu etkinlikleri artık yapmak istemiyor olması veya genel bir mutsuzluk hissi yaşaması olup depresyona bağlı ilk ortaya çıkan belirtidir (Sarman 2012). Doğal afetlerin bu yaş grubu üzerinde oluşturduğu psikolojik travmanın ilk göstergesini TSSB oluşturur. İkinci psikolojik travma belirtisi ise depresyondur (Felix vd. 2011; Cheng vd. 2018).

Anksiyete (Kaygl) Bozuklukları: Beynin tehlikeli bir durum hissettiğinde geliştirdiği bir adaptasyon davranışıdır (Göker vd. 2015). Anksiyete bozuklukları; çocuğun içinde bulunduğu stresli duruma bağlı gelişir. Anksiyete; otonom sinir sisteminde meydana gelen terleme, titreme, k1zarma gibi fizyolojik belirtiler, gerginlik, huzursuzluk gibi duygularla kendini gösteren ve çocuğun içinde bulunduğu durumu sürekli stres unsuru olarak algılamasına neden olan durum olarak da ele alınabilir (Demiriz ve Ulutaş2003). Sürekli anksiyete; Hensley ve Varela (2008) tarafindan yapılan çalışmada çocuklarda görülen somatik yakınmalar ile ilişkili bulunmuştur. Sürekli anksiyete düzeyi yüksek çocukların olumsuz fizyolojik tepkiler için daha fazla risk altında olduğu belirtilmiş̧ir.

Patolojik Yas: Patolojik yas çocuğun yas sürecini sağlıklı bir şekilde tamamlayamaması ve belirtilerin altı aydan uzun sürmesidir (Bildik 2013). Çocuğun kişisel özellikleri, kültürel ve dini inancı, daha önceki ruhsal sağlık sorunları, ölümü algılama biçimi, kaybedilen kişinin çocuk için önemi, ailenin sosyoekonomik durumu, çocuğun yas süreci ile baş etme biçimi, yeterli sosyal desteğin sağlanamaması yas tepkilerini etkileyen değişkenlerdir (Ürer 2017).

\subsection{Yaralanma/Sakatlanma, Bulaşıcı Hastalıklar ve Beslenme Sorunları}

Afetler çocukların ve üst yaş grubu ergen ve genç bireylerin yaralanmalarına, sakatlanmalarına, kaybolmalarına, ebeveynlerini kaybetmelerine ya da ailelerinden ayrilmalarına, yerlerinden edilmelerine, temiz suya ve gidaya ulaşmaktaki güçlükler nedeni ile yetersiz beslenme bozukluğu yaşamalarına (malnütrisyon) neden olabilir. Tüm bu riskler bu yaş grupları için afet öncesi dönemlerde de tehdit unsurudur. Afet sürecinde ise sağlık taleplerinin artması ve mevcut sağlık hizmetlerinin yetersiz kalması sonucu bu süreçler daha zor yaşanır hale gelir (Çalışkan 2015). Doğal afetlerden en çok etkilenen ve özel ilgi ve dikkat gerektiren grubun çocuklar, ergenler ve yakın yaş grubu gençler olduğunu belirtmiştir (Bhadra 2015).

Doğal afetlerden sonra çocuklar bulaşıcı hastalıklara karşı daha savunması hale gelirler. Bozulan alt yapı, değişen çevre şartları, su ve besin kaynaklarının kirlenmiş olması, temiz su ve besin kaynaklarının temininde yaşanan güçlükler, katı ve sıvı atık kontrollerinin yeterince sağlanamaması, sağlık hizmetlerinin aksaması, durması veya sağlık hizmetlerine erişimin kısıtlanması, kızamık gibi aşı ile koruyuculuk sağlanabilen hastalıklara karşı çocukların bağışıklık sisteminde gelişebilen hastalıklar, kalabalık yaşam alanlarında dört haftadan daha uzun süre yaşamak zorunda kalınması, kişisel hijyenin yeterince sağlanamaması, afetlerde ortaya çıkabilecek bulaşıcı hastalıklara ve korunma yollarına dair bilgi eksiklikleri, başıboş hayvan ve vektör kontrollerinin yeterince yapılamaması, hayatını kaybetmiş bireylerin defin işlemlerinin geciktirilmesi, cesetlerin kamp alanlarına yakın yerlerde ve sağlıksız koşullarda muhafaza edilmesi gibi birçok etken afetlerden sonra çocuklarda hem bulaşıcı hastalık görülme riskini hem de bu hastalıkların yayılma hızını arttırır (Pascapurnama vd. 2018; Ekşi 2016; Özcebe 2013; Watson vd. 2007).Doğal afetlerden sonra meydana gelen ölümlerin dörtte üçünden fazlası bulaşıcı hastalıklara bağlı gelişir (Gözübüyük vd. 2015). Doğal afetlerin sağlık üzerindeki bu etkisi üç dönemde değerlendirilmektedir (Uçku 2001).

Doğal afetlerin kurulu düzeni bozarak, beslenme ortamının kaybolmasına neden olduğunu ve çocukların gelişimini bozduğunu savunmuştur. Yaşanan doğal afetlerin onları daha savunmasız ve geleceğe karamsar bakan bireyler haline getirdiğini belirtmiştir. Bhadra (2015) çalışmasında çocukların korunmasını sağlamak için okul-toplum temelli stratejilerin kullanılması gerektiğini savunmaktadır.

\section{Bulgular ve Tartışma}

Afetler; yeri, zamanı, etkileme seviyesi ve sıklığı önceden kestirilemeyen, yaralanmalara, sakatlanmalara, can ve mal kayıplarına neden olan doğa olaylarıdır. Yaşanan afetler; can kayıplarına neden olmalarının yanında ülkelerin ekonomik gelişimine de ciddi birer darbedirler. 
Az gelişmiş ve gelişmekte olan ülkeler yıllık ekonomik kazançlarının \%1-2'sini yaşanan afetler sonucu yitirirler. Türkiye'de ise son 60 yılda yaşanan afetlerin dolaylı ve doğrudan etkileri sonucu oluşan ekonomik kayıpların ülkemize etkisi Gayri Safi Milli Hasıla'nın \%3'ü kadar olmuştur (AFAD 2015). EM-DAT verilerine göre 2017 y1lında dünyada 122 ülkeyi etkileyen 318 doğal afet meydana gelmiştir. Bu afetlerden 96 milyon insan etkilenmiş ve 9503 kişi yaşamını yitirmiştir. 2017 y1lında meydana gelen ölümlerin \%90’ına iklimsel, hidrolojik ve meteorolojik afetler neden olmuştur. Afetlerden etkilenen insanların ise \%60'1 sel felaketlerinden etkilenmiştir (CRED 2018).

Literatürde yer alan çalışmalar incelendiğinde doğal afetlerin çocuklar ve başta ergen bireyler olmak üzere gençler üzerindeki etkilerini araştıran çok çeşitli çalışmalar olduğu tespit edilmiştir. Bugün bu yaş grupları için afetlerden sonra yapılmış en kapsamlı çalışmaların TSBB, depresyon ve anksiyete gibi psikolojik tepkiler üzerine odaklandığı görülmektedir. Yakın zamanlı yapılan çalışmaların ise okul başarısı, madde kullanımı, intihar düşüncesi, kaygı bozuklukları, başa çıkma stratejileri ve travma sonrası büyüme gibi afetlerin olumlu ve olumsuz etkilerine odaklandığı görülmüştür.

Çocuğun yaşı, cinsiyeti, eğitim durumu, tıbbi özgeçmişi ve daha önceki afet tecrübesi gibi kişisel ve gelişimsel özellikleri, doğal afetlerin yol açtığı hasar derecesi, doğal afet sonrası aile üyelerinin, arkadaşlarının ve sevdiklerinin kaybı, doğal afetlerden sonra afetzedelere sağlanan sosyal destek mekanizmaları doğal afetlerin çocuklar ve ergenler üzerindeki etkilerini belirleyen unsurlardır.

\section{Sonuçlar}

Dünya genelinde meydana gelen afetlerden her yıl yaklaşık 250 milyon insanın etkilendiği düşünülmektedir. Önümüzdeki on y1l içinde de bu sayının artarak 350 milyon insana ulaşacağ oluşturacağı düşünülmektedir. Çalışma kapsamında elde edilen bulgular göz önüne alınarak doğal afetlerin çocuklar ve ergen bireyler üzerindeki fiziksel, sosyal, davranışsal ve psikolojik olumsuz etkilerinin azaltılabilmesi için yapılması gerekenler aşağıda sıralanmıştır;

- Doğal afetlerden önce gerçekleştiren afet hazırlık çalışmalarını da dikkate alan afet ve acil yardım planları hazırlanmalıdır. Hazırlanan afet ve acil yardım planlarında çocuk ve ergenelerin, temel ihtiyaçları ve kapasiteleri de değerlendirilmeli ve ihmal edilmemelidir.

- Çocuklar en çok bilmedikleri kavramlardan korkarlar. Eğitim öğretim faaliyetlerinde afetler, afetlerden korunma ve ilk yardım gibi çocukların ve ergenlerin afet farkındalığını arttıracak konulara yer verilmeli, farkındalıklarının arttırılması için, eğitimi destekleyici afet tatbikat alanları oluşturulmalıdır.

- Sosyal medya ve kitle iletişim araçları bu yaş grubundaki bireylerin doğal afetler hakkında daha çok farkındalığının oluşması için çalışmalarda aktif olarak kullanılmalıdır.

- Üniversite öğrencilerinin olası afet riskleri, önleme, müdahale ve iyileştirme çalışmaları devlet tarafından desteklenmeli ve teşvik edilmelidir.

- Doğal afetlerin neden olduğu kargaşa ortamında çocukların sömürülmesini, istismarını ve suça karışmalarını önlemek için yerel ve ulusal yetkilere sahip görevliler birlikte çalışmalıdır.

- Öğretmenler, ebeveynler, afet bölgesinde görevli sağlık çalışanları, arama ve kurtarma çalışanları, gelişim psikolojisi, çocuk ve ergen psikolojisi, fiziksel yaralanma mekanizmaları, davranış değişiklikleri, psikolojik travma belirtileri alanlarında eğitilmelidir. Bu sayede afetlerden sonra olası sağlık sorunlarının tespiti kolaylaşacak ve zaman kaybetmeden hızlı müdahalelerin gerçekleşmesi sağlanacaktır.

$\mathrm{Bu}$ çalışma kapsamında elde edilen bulguların, bundan sonra yapılacak çalışmalara rehber niteliğinde olacağı düşünülmektedir.

\section{Teşekkür}

Bu çalışmanın gerçekleştirilmesinde önerilerinden yararlanılan Mustafa Karabulut'a teşekkür ederiz.

\section{Kaynaklar}

AFAD, (2014), Açıklamalı Afet Yönetimi Terimleri Sözlü̆̆̈̈, T.C.BaşbakanlıkAfet ve Acil Durum Yönetimi Başkanlı̆̆ı, 216ss.

AFAD, (2015), Bütünleşik Tehlike Haritalarının Hazırlanması Heyelan-Kaya Düşmesi Pratik Kılavuz, T.C.BaşbakanlıkAfet ve Acil Durum Yönetimi Başkanlığı, Ankara,42ss.

Akcanbaş M., (2009), Çocuklarda ve Gençlerde Afet Psikososyolojisi El Kitabı (I), http://mertakcanbas.blogcu.com/cocuklar-vegenclerde-afet-psikososyolojisi-el-kitabi-i/6232106, [Erişim 29 Ağustos 2018].

Akyılmaz D., Karka O., (2011). Afetlerde Psikolojik İlkyardim, İstanbul AFAD yayınları, 36ss.

Arpacı T., Aslan Y., Atıcı A., Atıcı Ş., Avlan D., Birbiçer H., Boleken E., Boneval C., Cengiz M., Derbent M., Ergin H., Gönüllü M., Gündüz M., Hallığlu O., Işık B., İlhan H., Kaya F., Koçak G., Mert E., Naycı A., Okuyaz Ç., Özdemir T., Polat S., Şanlı C., Tansuğ N., Turhan A.H., Uçar B., Üçkuyu Y., Vargün R., (2011), Çocuklarda İleri Yaşam Desteği Programı Uygulayıcı Kursu Kitabı, (Atıcı A. Ed.), Sağlık Bakanlığı Yayınları, 118ss. 
Aycan S., Toprak İ., Yüksel B., Özer H., Çakır B., (2002), Afet Durumlarında Beslenme Hizmetleri, Sağlık Bakanlığı Temel Sağlık Hizmetleri Genel Müdürlüğü, 13ss.

Bhadra S., (2015), Psycho-Social Support for Protection of Children in Disasters, Child Safety, Welfare and Well-being. $259-278$.

Bildik T., (2013), Ölüm, kayıp, yas ve patolojik yas, Ege Tıp Dergisi, 52(4),223- 229.

Bulakbaşı M., (2015), Sağlık Tanımı, Sağlık Hizmetleri, Türk Sağlık Sistemi, https://neu.edu.tr/wp-content/uploads/2015/11/Sa\%C4\% 9Fl\%C4\%B1k-Tan\%C4\%B1m\%C4\%B1-Sa\%C4\%9Fl\%C4\%B1k-Hizmetleri-T\%C3\%BCrk-Sa\%C4\%9Fl\%C4\%B1kSistemi5.pdf, [Erişim 29 Ağustos 2018].

Bulut S., (2009). Depremden Sonra Çocuklarda Görülen Travma Sonrası Stres Tepkilerinin Yaş ve Cinsiyet Açısından Karşılaştırılması, Türk Psikolojik Danışma ve Rehberlik Dergisi, 4(31), 43- 51.

Cheng J., Liang Y., Fu L., Liu Z., (2018), Posttraumatic stress and depressive symptoms in children after the Wenchuan earthquake, European Journal of Psychotraumatology, 9(1):1472992, 1- 12.

Coffman S., (1998), Children's ReactionstoDisaster, Journal of PediatricNursing, 13(6): 376- 382.

CRED, (2018), Natural disastersin 2017: Lowermortality, highercost, https://cred.be/sites/default/files/CredCrunch50.pdf, [29 Ağustos 2018].

Demiriz S., Ulutaş İ., (2003), 9- 12 Yaş Çocuklarının Kaygı Düzeylerinin Bazı Değişkenlere Göre İncelenmesi, Ege Eğitim Dergisi, 3 (1), 1-9.

Ekici S., Tuncel G., (2015), Göç ve İnsan, Birey ve Toplum, 5(9), 9-22.

Ekși A., (2016), Afetlerden Sonra Ortaya Çıkabilecek Çevresel Risklerin Yönetimi, Hastane Öncesi Dergisi,1(2), 15- 25.

Erden G., Gürdil G., (2009), Savaş Yaşantılarının Ardından Çocuk ve Ergenlerde Gözlenen Travma Tepkileri ve Psiko-Sosyal Yardım Önerileri, Türk Psikoloji Yazıları, 12(24), 1- 13.

Erden G., Erman H., Öztan N., (2011), Çocuklar ve ergenlerde travmatik yaşantılar ve başetme, Afetlerde Psikososyal Hizmetler Birliği, Psikososyal Uygulamalar Katılımcı Kitabı, ss.97-141.

Felix E., Hernandez L.A., Bravo M., Ramirez R., Cabiya J., Canino G., (2011), Natural Disaster and Risk of Psychiatric Disorders in Puerto Rican Children, Journal of Abnormal Child Psychol, 39(4), 589-600.

Felix E., Kaniasty K., You S., Canino G., (2016), Parent- Child Relationship Quality and Gender as Moderators of the Influence of Hurricane Exposure on Physical Health Among Childrenand Youth, Journal of PediatricPsychology,41(1), 73-85.

Gökçe O., Tetik Ç., (2012), Teoride ve Pratikte Afet Sonrası Iyileştirme Çalışmaları, AFAD yayınları, 270ss.

Göker Z., Güney E., Dinç G., Hekim Ö., Üneri Ö.Ş., (2015), Çocuk ve Ergenlerde Anksiyete İle İlişkili Bozuklukların Klinik ve Demografik Özellikleri: Bir Yıllık Kesitsel Bir Örneklem, Klinik Psikiyatri, 18, 7-14.

Göktepe K., (2014), Çocukluk Çağı Travma Sonrası Duygusal Stres Ölçeğinin Uyarlama, Geçerlik ve Güvenirlik Çalışması, Yüksek Lisans Tezi, Üsküdar Üniversitesi, Türkiye.

Gözübüyük A.A., Duras E., Dağ H., Arıca V., (2015), Olağan üstü Durumlarda Çocuk Sağlığı, Journal of Clinical and Experimental Investigations, 6(3), 324-330.

Hansel T.C., Osofsky J.D., Osofsky H.J., Friedrich P., (2013), The Effect of Long-Term Relocation on Child and Adolescent Survivors of Hurricane Katrina, Journal of Travmatik Stress, 26, 613-620.

Hansel T.C., Osofsky J.D., Osofsky H.J., (2015), Louisiana State University Health Sciences Center Katrina Inspired Disaster Screenings (KIDS): Psychometric Testing of the National Child Traumatic Stress Network Hurricane Assessment and Referral Tool, Child \& Youth Care Forum, 44(4), 567-582.

Hensley L., Varela R.E., (2008), PTSD Symptoms and Somatic Complaints Following Hurricane Katrina: The Roles of Trai tAnxiety and Anxiety Sensitivity. Journal of Clinical Child and Adolescent Psychology, 37(3), 542-552.

Işık Ö., Aydınlığlu H.M., Koç S., Gündoğdu O., Korkmaz G., Ay A., (2012), Afet Yönetimi ve Afet Odaklı Sağllk Hizmetleri, Okmeydanı Tip Dergisi, 28(2), 82-123.

İşmen E., (2001), Deprem Yaşantısına Bă̆lı Travma ve Çocuklar Üzerindeki Etkisi, Abant İzzet Baysal Üniversitesi, Eğitim Fakültesi Dergisi, 1(2), 80-104.

Kadığlu M., (2008), Modern, Bütünleşik Afet Yönetimi Temel İlkeleri, Kadığlu M., Özdamar E. (editörler), Afet Zararlarını Azaltmanın Temel İlkeleri, JICA Türkiye Ofisi Yayınları, ss.1-34.

Kadığlu M., (2011), Afet Yönetimi Beklenilmeyeni Beklemek, En Kötüsünü Yönetmek, T.C. Marmara Belediyeler Birliği Yayını, 219 ss.

Karakaya I., Ağaoğlu B., Çoşkun A., Şişmanlar Ş.G., Yıldız Ö.Ö., (2004), Marmara Depreminden Üç Buçuk Yıl Sonra Ergenlerde TSSB, Depresyon ve Anksiyete Belirtileri, Türk Psikiyatri Dergisi, 15(4), 259-263.

Kaştan Y., (2015), Türkiye'de Göç Yaşamış Çocukların Eğitim Sürecinde Karşılaşılan Problemler, Uluslararası Sosyal ve Eğitim Bilimleri Dergisi, 2(4), 216-229.

Koç M., (2004), Gelişim Psikolojisi Açısından Ergenlik Dönemi ve Genel Özellikleri, Sosyal Bilimler Enstitüsü Dergisi, 17: 231 - 238.

Leblebici Ö., (2004), Doğal Afetlerde Kriz Yönetimi, Yüksek Lisans Tezi, Gazi Üniversitesi, Ankara, Türkiye.

Limoncu S., Atmaca A.B., (2018), Çocuk Merkezli Afet Yönetimi, Yıldız Teknik Üniversitesi Mimarlık Fakültesi E- Dergisi, 13(1), 132-143.

Lynch J., Wathen J., Tham E., Mahar P., Berman S., (2010), Disasters and Their Effects on Children, Advances in Pediatrics, 57, 731.

Maclean J.C., Popovici I., French M.T., (2016), Are natural disasters in early childhood associated with mental health and substance use disorders as an adult?, Social Science \& Medicine, 151: 78-91.

MEB, (2011), Travmalar 1, T.C. Milli Eğitim Bakanlı̆̆1, Acil Sağlık Hizmetleri, http://megep.meb.gov.tr/mte_program_modul/ moduller_pdf/Travmalar\%201.pdf, [Erişim 29 Ağustos 2018].

MGM, (2018), Türkiye2017 Yılı İklim Değerlendirmesi, T.C. Orman ve Su İşleri Bakanlığı Meteoroloji Genel Müdürlüğü, Araştırma Dairesi Başkanlığı, https://www.mgm.gov.tr/FILES/iklim/yillikiklim/2017-iklim-raporu.pdf, [Erişim 29 Ağustos 2018].

Oral İ., Bozbey M.M., Özcan G.G., Özdemir A., Güler A., Çoşar A.E., Aslan S., Soylu F., Hatipoğlu Ç., (2017), Afetlerde Beslenme Hizmetleri Kılavuzu, Türk Kızılayı Yayınları, 88ss. 
Özcebe H., (2013), Afetlerde Çocuk ve Ergen Să̆llğı Hizmetleri, Acil ve Afet Durumlarında Sağlık Yönetimi, Hacettepe Üniversitesi Yayınları, 243-254.

Pascapurnama D.N., Murakami A., Chagan- Yasutan H., Hattori T., Sasaki H., Egawa S., (2018), Integrated health education in disaster risk reduction: Lesson learned from disease outbreak following natural disasters in Indonesia, International Journal of Disaster Risk Reduction, 29, 94-102.

Pfefferbaum B., Houston J.B., North C.S., Regens J.L., (2008), Youth's Reactions to Disaster and the Factors That Influence Their Response, Prev. Res. Author Manuscript, 15(3): 3-6.

Sarman A., (2012), Elazı̆̆ İli Karakoçan İlçesinde Yaşanan Yıkıcı Deprem Sonrasında, Depremi Yaşayan İlköğretim Çă̆ı Çocuklarda Kaygl Düzeyi, Depresyon Belirtileri ve Etkileyen Faktörler, Yüksek Lisans Tezi, Fırat Üniversitesi, Elazığ. Türkiye.

Sawada Y., Takasaki Y., (2017), Natural Disaster, Poverty, and Developmen: An Introduction, World Development, 94: 2-15.

Uçku R., (2001), Doğal Afetler ve Olağanüstü Durumlarda Görülen İnfeksiyon Hastalıkları: Kontrol Önlemleri, ANKEM Dergisi, 15 (3): 651-656.

Ürer E., (2017). Cocuklarda Ölüm ve Yas Üzerine Bir İnceleme, Dini Araștırmalar, 20(52), 131-140.

Yavuz A., Dikmen S., (2015), Doğal Afetlerin Zararlarının Finansmanında Kullanılan Afet Öncesi Finansal Araçlar, Marmara Üniversitesi Siyasal Bilimler Dergisi, 3(2), 303-322.

Yıldız A.N., (2013), İlkyardım Eğitiminin ve Afetlerde İlkyardım Uygulamalarının Önemi, Acil ve Afet Durumlarında Sağlık Yönetimi, Hacettepe Üniversitesi Yayınları, 27-34.

Yüksel T., (2016), Adolesanlarda Madde Kullanımı ve Bağımlılı̆̆ı, Adolesanda Psikososyal Sorunlar, (Haspolat Y.K., Yüksel T., Yolbaş İ. Ed.), ss.95-99.

Watson J.T., Gayer M., Connolly M.A., (2007), Epidemics After Natural Disasters, Emerging Infectious Diseases, 13(1), 1-5. 